\title{
Corrigendum to "Use of indirect calorimetry to evaluate utilization of energy in lactating Jersey dairy cattle consuming diets with increasing inclusion of hydrolyzed feather meal" (J. Dairy Sci. 103:4206-4217)
}

\section{L. Morris, J. V. Judy, and P. J. Kononoff}

Tissue energy was calculated incorrectly. The corrected equation is listed below, as well as a corrected Table 3 , with corrected tissue energy and $\mathrm{NE}_{\mathrm{L}}$ values calculated using tissue energy (corrected text shown in bold).

Tissue energy (Mcal of NEL/d) = positive residual energy $\times \mathbf{k}_{\mathrm{G}} / \mathbf{k}_{\mathbf{T}}$ or negative residual energy $\times \mathbf{k}_{\mathbf{T}}$,

where $\mathrm{k}_{\mathrm{T}}$ is the efficiency of utilizing body reserves for milk energy production, and $\mathrm{k}_{\mathrm{G}}$ is the efficiency of utilizing ME intake for tissue gain.

Table 3. Effects of treatments containing hydrolyzed feather meal fed to lactating Jersey cows on $\mathrm{O}_{2}$ consumption, $\mathrm{CO}_{2}$ and $\mathrm{CH}_{4}$ production, respiratory quotient, and energy utilization

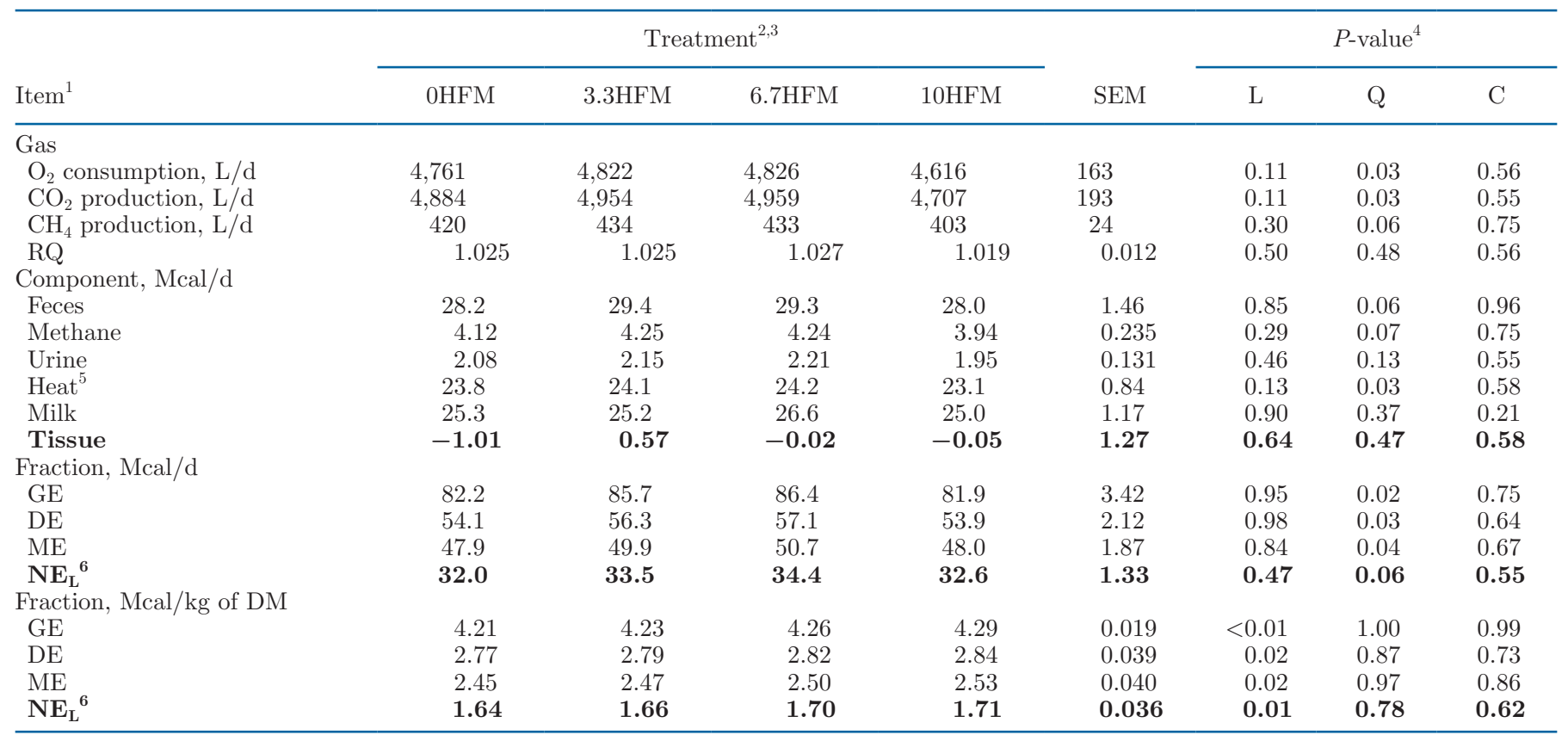

${ }^{1} \mathrm{GE}=$ gross energy; $\mathrm{DE}=$ digestible energy; $\mathrm{RQ}=$ respiratory quotient, $\mathrm{CO}_{2}$ production $/ \mathrm{O}_{2}$ consumption, $\mathrm{L} / \mathrm{L}$.

${ }^{2}$ Treatments: $0 \mathrm{HFM}=0 \%$ hydrolyzed feather meal; $3.3 \mathrm{HFM}=3.3 \%$ hydrolyzed feather meal; $6.7 \mathrm{HFM}=6.7 \%$ hydrolyzed feather meal; $10 \mathrm{HFM}$ $=10 \%$ hydrolyzed feather meal.

${ }^{3}$ Least squares means; largest standard error of treatment mean is shown.

${ }^{4} \mathrm{~L}=$ linear; $\mathrm{Q}=$ quadratic; $\mathrm{C}=$ cubic.

${ }^{5}$ Heat $=3.866 \times \mathrm{O}_{2}+1.200 \times \mathrm{CO}_{2}-0.518 \times \mathrm{CH}_{4}-1.431 \times \mathrm{N}$ (Brouwer, 1965).

${ }^{6} \mathrm{NE}_{\mathrm{L}}=0.080 \times \mathrm{BW}^{0.75}+$ milk energy + tissue energy corrected for efficiency of conversion to milk energy (NRC, 2001).

\section{REFERENCE}

Morris, D. L., J. V. Judy, and P. J. Kononoff. 2020. Use of indirect calorimetry to evaluate utilization of energy in lactating Jersey dairy cattle consuming diets with increasing inclusion of hydrolyzed feather meal. J. Dairy Sci. 103(5):4206-4217. https://doi.org/10.3168/jds.2019 -17762 . 